\title{
Mechanisms of antioxidant defense in the state of post-hypoxia in Phrynops geoffroanus (Testudines: Chelidae)
}

\author{
N.R.A. Costa ${ }^{1,2}$, L.P.R. Venancio ${ }^{1,2,3}$ and C.R. Bonini-Domingos ${ }^{1,2}$ \\ ${ }^{1}$ Centro de Estudos de Quelônios, Departamento de Biologia, \\ Instituto de Biociências, Letras e Ciências Exatas, \\ Universidade Estadual Paulista “Júlio de Mesquita Filho”, São José do Rio Preto, \\ SP, Brasil \\ ${ }^{2}$ Laboratório de Hemoglobinas e Genética das Doenças Hematológicas, \\ Departamento de Biologia, Instituto de Biociências, Letras e Ciências Exatas, \\ Universidade Estadual Paulista "Júlio de Mesquita Filho", São José do Rio Preto, \\ SP, Brasil \\ ${ }^{3}$ Centro de Ciências Biológicas e da Saúde, \\ Universidade Federal do Oeste da Bahia, Barreiras, BA, Brasil \\ 2016. Pós-Graduação em Biologia Animal, Instituto de Biociências, \\ Letras e Ciências Exatas, Universidade Estadual Paulista "Júlio de Mesquita \\ Filho", São José do Rio Preto, SP, Brasil \\ Master's thesis. Orienting Prof.: C.R. Bonini-Domingos, Co-orienting \\ Prof.: L.P.R.Venancio \\ Corresponding author: C.R. Bonini-Domingos \\ E-mail: claudiabonini@sjrp.unesp.br \\ Genet. Mol. Res. 15 (4): gmr15049308 \\ Received September 20, 2016 \\ Accepted September 20, 2016 \\ Published October 17, 2016 \\ DOI http://dx.doi.org/10.4238/gmr15049308 \\ Copyright (C) 2016 The Authors. This is an open-access article distributed under the terms of \\ the Creative Commons Attribution ShareAlike (CC BY-SA) 4.0 License.
}

Genetics and Molecular Research 15 (4): gmr15049308 
Phrynops geoffroanus (Testudines: Chelidae), comprises a group of reptiles that are tolerant to variations in environmental oxygen availability. Due to this characteristic, they are considered an excellent model for studies that aim the understanding of the physiological and biochemical mechanisms involved in the resistance to oxidative stress and cell damage. During its evolution, some turtles have developed mechanisms that allow them to survive the oxygen deprivation and consequent reoxygenation of tissues, a condition known to release the so-called reactive oxygen species (ROS), a group of molecules that are capable of interacting with other cell components, in some cases, leading to oxidation of essential cell components, such as proteins, DNA, and fatty acids. These mechanisms are related to turtles high-antioxidant capacity, that are able to combat the deleterious effects of ROS and, thus, adequately survive after the period they were under stress. Therefore, this study aimed to understand the antioxidant mechanisms that act in the organism after the reoxygenation, due to the previous period of induced hypoxia in P. geoffroanus. We evaluate the activity of some antioxidant enzymes, as well as the existence of cellular damage in brain, heart, liver and pancreas. Twenty individuals were collected in Preto river, that belongs to the basin Turvo/ Grande, in the city of São José do Rio Preto, São Paulo. The animals were acclimated for 120 days, and, thereafter, the normoxia and hypoxia-reoxygenation experiments were conducted under controlled temperatures of $27^{\circ}$ and $17^{\circ} \mathrm{C}$, corresponding to the temperature range of Preto river during the year. After the extraction of tissues, analysis of the enzymatic activity of catalase, glutathione reductase, glutathione S-transferase and glutathione peroxidase, as well as analysis of the levels of lipid peroxidation by quantification of malondialdehyde, were performed. We concluded that the enzymatic activity was not higher in all tissues exposed to reperfusion. It was observed the existence of cellular damage due to lipid peroxidation, especially in organisms exposed to reoxygenation, concluding that the damage exists, although it is very low compared to other animals. The results of this study can not only elucidate conservation issues of a species often neglected, but also contribute to a better understanding of the history of life, biochemistry and cell biology in these animals, as well as the understanding of oxidative stress repair mechanisms.

Key words: Oxidative stress; Enzymatic activity; Chelidae

\section{ACKNOWLEDGMENTS}

Research supported by FAPESP (Process \#2014/22398-9 and Process \#2012/140482). Thanks are due to Gabriela de Sousa Martins, Camila Zucchini de Souza, Lucas Ramos Pereira, Dr. Danilo Grünig Humberto da Silva, and Dr. Eduardo Alves de Almeida (UNESP/ IBILCE).

Genetics and Molecular Research 15 (4): gmr15049308 